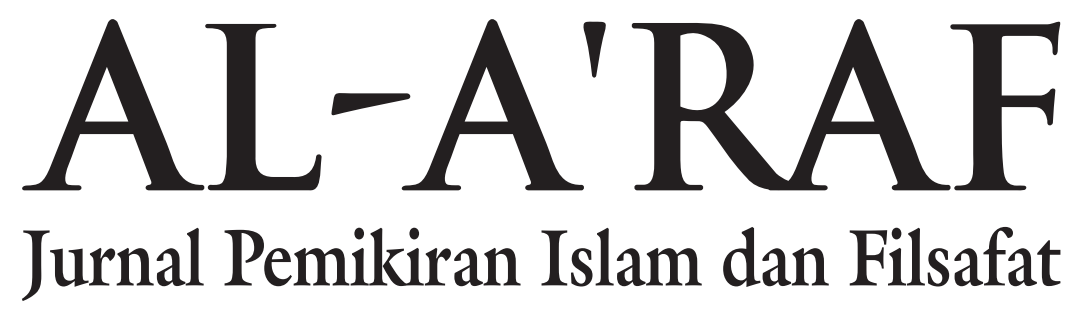




\title{
AL-A'RAF \\ Jurnal Pemikiran Islam dan Filsafat
}

\section{Editorial Team:}

\author{
Editor in-Chief \\ Islah Gusmian, IAIN Surakarta
}

\section{Editorial Board}

Mahrus eL-Mawa, Kementerian Agama Republik Indonesia Jakarta

Media Zainul Bahri, UIN Syarif Hidayatullah Jakarta

Muhammad Irfan Helmy, IAIN Salatiga

M. Endy Saputro, IAIN Surakarta

Nashruddin Baidan, IAIN Surakarta

\section{Managing Editor}

Nur Kafid, IAIN Surakarta

\section{Editor}

Subkhani Kusuma Dewi, UIN Sunan Kalijaga, Yogyakarta

Yuyun Sunesti, UNS Solo

\section{Editorial Assistant}

Nur Rohman, IAIN Surakarta

Siti Fathonah, IAIN Surakarta

\section{Reviewer}

M. Faisol Fatawai, UIN Maulana Malik Ibrahim, Malang

Abad Badruzzaman, IAIN Tulung Agung

Fadhli Lukman, Universität Freiburg, Germany

Ahmad Fawaid Sjadzili, IAIN Madura

Ahmad Fuad Fanani, University of Toronto, Canada

Jajang A Rohmana, UIN Sunan Gunung Djati

Kamaruzzaman Bustamam Ahmad, UIN Ar-Raniry-Banda Aceh

\section{Alamat Redaksi:}

Fakultas Ushuluddin dan Dakwah, IAIN Surakarta.

Jl. Pandawa No. 1, Pucangan, Kartasura, Jawa Tengah, 57168

Phone: +62271-781516, Fax: +62271-782774.

$$
\text { e-mail: jurnal.alaraf@gmail.com }
$$

web: http:// ejournal.iainsurakarta.ac.id/index.php/al-araf 


\section{AL-A'RAF \\ Jurnal Pemikiran Islam dan Filsafat}

\section{Tabel of Content}

Kopi, Warung Kopi, dan Potensi Studi Keislaman

Aflahal Misbah

Genealogi Revolusi Paradigma Pemikiran Keislaman

Nahdlatul Ulama

Tejo Waskito

Analisis Antropologi-Struktural Kisah Musa dan

Khidzir dalam Alqur'an

M. Yaser Arafat

Kompleksitas Simbol dan Representasi Makna dalam

Tradisi Rajaban Masyarakat Kebumen

Siti Fathonah

John Wansbrough: Studi Atas Tradisi dan Instrumen

Tafsir Alqur'an Klasik

Syamsul Wathani

Tarekat, Kesalehan Ritual, Spiritual dan Sosial: Praktik Pengamalan Tarekat Syadriliyah di Banten

E. Ova Siti Sofwatul Ummah

Paradigma Integrasi-Interkoneksi di Tengah Kompleksitas Problem Kemanusiaan

Syahrial Labaso

Indeks Penulis

Ucapan Terima kasih Kepada Mitra Bebestari 


\title{
AL-A'RAF
}

Jurnal Pemikiran Islam dan Filsafat

\section{GENEALOGI REVOLUSI PARADIGMA PEMIKIRAN KEISLAMAN NAHDLATUL ULAMA}

Tejo Waskito

STEBI Lampung

\begin{tabular}{l}
\hline Keywords: \\
Geneology, NU, \\
Revolution, \\
Paradigm \\
\hline
\end{tabular}

\begin{abstract}
Abstrak
Artikel ini mencoba melacak genealogi revolusi paradigma pemikiran keislaman di NU dan berbagai kemungkinan yang ditimbulkannya. Melalui studi kepustakaan dengan pendekatan analisis wacana, hasilnya menunjukkan bahwa genealogi revolusi paradigma keislaman NU lahir akibat dialektika internal dan eksternal yang dijembatani oleh multi-epistemologi. Dilatarbelakangi oleh peristiwa 'rekonsiliasi politik' yang disebut 'kembali ke khittah 1926' di Situbondo pada 1984, NU mengalami pergeseran orientasi, tidak hanya pada ranah politik tetapi juga paradigmatik. Akibatnya, terjadi mobilitas sosial-intelektual yang ditandai dengan menjamurnya wacana sosial dan intelektual di kalangan generasi mudanya. Dominasi aktivitas ini melahirkan gerakan revolusioner di bidang paradigma keislaman NU: teologi Aswaja yang semula dipahami sebagai doktrin menjadi metodologi berpikir (manhaj alfikr); ekspansi metodologi instinbath hukum, dari qauly ke manhajy; dan pergeseran perjuangan politik, dari arena politik struktural ke politik kultural. Wacana ini menjadi massif berkat dukungan Abdurrahman Wahid, figur ideal yang dikenal sebagai lokomotif gerakan kultural NU.
\end{abstract}

\section{Abstract}

This article tries to track genealogy of the Islamic revolutionary paradigm of thought in NU and its various possibilities have arisen. Based on the library studies using the analytical discourse approach, the result revealed that the genealogy of the Islamic paradigm of $N U$ was born due to the internal and external dialectics bridged by multi-epistemology. Based on the 'political reconciliation' event which is called 'returning to khittah 1926' in Situbondo in 1984, NU experienced a shift orientation, not only in the political sphere but 
also paradigmatically. Hereby, there was social-intellectual mobility marked by the proliferation of social and intellectual discourse among NU's young generation. The dominance of this activity leading to revolutionary movement in the field of NU's Islamic paradigm: Aswaja's theology which was originally understood as a doctrine became a thinking methodology (manhaj alfikr); expansion of the legal institution's methodology, from qauly to manhajy; and shifting political struggle, from structural political arena to cultural politics. This discourse became massive among Nu's young generation caused by the support of Abdurrahman Wahid, the ideal figure known as a locomotive of the NU cultural movement.

\section{Pendahuluan}

Pasca 'rekonsiliasi politik' dengan rejim Orde Baru yang ditandai dengan kembalinya Nahdlatul Ulama (NU) ke khittah $1926^{1}$ di Situbondo pada tahun 1984, pergumulan pemikiran di lingkungan NU memasuki babak baru. Sebuah babak, di mana generasi muda NU memainkan peran penting dan posisi strategis di tubuh NU. Mereka bergumul dan berwacana mendesain kerangka pembaharuan. Bukan sekadar menyangkut pergeseran arah 'kiblat organisasi', tetapi juga upaya rekonstruksi pandangan dunia (worldview) keislaman, yakni terkait dengan nilai-nilai kesadaran keberislaman: berupa nilai-nilai keislaman yang diuji dalam aktualitas yang terus bergejolak (fiqh), ${ }^{2}$ nilai-nilai yang dipertahankan dari tindakan merusak kekuatan sentrifugal (teologi) ${ }^{3}$, dan nilai-nilai yang dianggap sebagai jaminan tunggal atas pengetahuan yang menyelamatkan (tasawuf).

Setelah mengalami kegalauan akut di dunia politik praktis, tahun 1984 berteparan dengan Muktamar NU ke-27 di Situbondo, NU menarik diri dari arena politik praktis dan kembali menjadi jam'iyyah diniyah. Kembalinya NU ke khittah 1926 berarti NU kembali ke pangkuan umat sebagaimana tujuan awal perjuangannya. Mengenai khittah selengkapnya baca Shiddiq Achmad, Khittah Nabdliyyah (Surabaya: Balai Buku, 2005), 96.

2 Muhammad Ulil Abshor, "Dinamika Ijtihad Nahdlatul Ulama (Analisis Pergeseran Paradigma Dalam Lembaga Bahtsul Masail NU)," Millati, Journal of Islamic Studies and Humanities 1, no. 2 (2016): 227-242.

3 Muhammad Masyhuri, "NU dan Paradigma Teologi Politik Pembebasan: Refleksi Historis Pasca Khittah," Wawasan: Jurnal Imiah Agama dan Sosial Budaya 1, no. 2 (2016): 158-178. 
Keputusan khittah 1926 tidak hanya mengantarkan NU keluar dari arena politik praktis, yang berimplikasi pada dominasi aktivitas sosialkultural dan menjamurnya wacana intelektual di kalangan generasi muda $\mathrm{NU},{ }^{4}$ termasuk munculnya istilah Islam Nusantara ${ }^{5}$ belakangan ini sebagai salah satu buktinya, tetapi juga menggugah kesadaran mereka untuk bertolak dari situasi sosio-kultural tertentu, yaitu memahami fenomena sosial secara kritis-tansformatif. Progresivitas wacana intelektualisme itu pada gilirannya mampu melampaui sekaligus meminggirkan paradigma tradisionalisme madzhabnya.

Inilah yang oleh Thomas S. Kuhn disebut sebagai fase munculnya revolusi paradigma ilmu pengetahuan. Ketika bangunan pemikiran yang dianggap mapan sudah tidak lagi memadai untuk menjawab problematika yang muncul akibat dialektika peradaban. ${ }^{6}$ Revolusi paradigma membuka kesadaran bahwa ilmu pengetahuan tidak selamanya bekerja dalam suasana obyektivitas yang mapan. ${ }^{7}$ Lalu genealogi sosial-kultural-transendental apakah yang sesungguhnya melatarbelakangi revolusi paradigma pemikiran keislaman NU? Sejauhmana revolusi paradigma tersebut berdampak terhadap tradisi pemikiran yang dianggap telah mapan? Dalam dimensi rasionalitas, artikel ini mencoba melacak genealogi revolusi paradigma keislaman NU dan berbagai kemungkinan logis yang ditimbulkan.

Dilihat dari genealogi pemikiran dan perilaku keberagamaan warganya, konstruksi dasar paradigma keislaman NU terkandung di dalam pokok-pokok ajaran ablussunnah wa aljama'ah (Aswaja). ${ }^{8}$ Konsep

4 Khoirun Niam, "Nahdlatul Ulama and the Production of Muslim Intellectuals in the Beginning of 21st Century Indonesia," Journal of Indonesian Islam 11, no. 02 (2017): 351-388.

5 Luqman Nurhisam and Mualimul Huda, "Islam Nusantara: A Middle Way?," QIJIS: Qudus International Journal of Islamic Studies 4, no. 2 (2016): 152-166.

6 Thomas S. Kuhn, The Structure of Scientific Revolutions (University of Chicago press, 2012), 92.

7 Nurkhalis, “Konstruksi Teori Paradigma Thomas S. Kuhn," Jurnal Ilmiah Islam Futura 11, no. 2 (2012): 79-99.

8 Penegasan NU sebagai "Organisasi Keagamaan Sunni” diperkuat pada 
Aswaja ala NU didasarkan pada pemikiran beberapa tokoh dalam hal teologi, fikih, dan tasawuf. Dalam hal teologi, NU menganut paham yang dibawa oleh Alasy'ari dan Almaturidi. Alasy'ari dikenal sebagai tokoh yang berhasil mensintesiskan 'pertikaian' teologis antara paham rasionalis absolut Mu'tazilah dengan seorang ahli hadith ekstrem literalis, Ahmad ibn Hanbal. ${ }^{9}$

Alasy'ari berhasil menjembatani 'pertikaian' keduanya dengan mengambil jalan tengah, berupa pengakuan terhadap rasionalitas, tetapi pada batas tertentu juga harus tunduk kepada wahyu. Gagasan ini kemudian dielaborasi lebih jauh oleh Imam Manshur Almaturidi hingga mendiaspora sebagai dogma. Pengikut ajaran Alasy'ari inilah yang pada satu Abad kemudian dilabeli sebagai ablussunnah wa aljama'ah oleh Alzabidi. Sebuah label yang pernah digunakan oleh Hasan Albasri (wafat $110 \mathrm{H}$ ) untuk merujuk pada komunitas "ahli ilmu dan ahli ibadah" yang pada waktu itu tidak memihak kepada Mu'awiyah, Syiah, dan Khawarij saat terjadi 'perseteruan' teologi.

Teologi Alasy'ari dan Almaturidi ini kemudian ditransformasikan ke dalam konteks masyarakat yang lebih aplikatif, seperti etika sosial dan transendental. Bagi kaum Nabdliyyin, the ultimate goal kehidupan manusia adalah penerimaan di sisi Allah. Aktivitas duniawi tidak diabaikan, tetapi diposisikan sebagai persiapan menuju eskatologi. Dalam kerangka inilah tasawuf memberi infrastruktur penting bagaimana melakukan pendalaman keimanan, sedangkan fikih memberi jalan terkait tata-cara beribadah dan ber-mu'amalah.

Tasawuf merupakan pengamalan tarekat; metode praktis mendekatkan diri kepada Allah dengan mengamalkan sejumlah zikir.

Muktamar NU ke-26 di Semarang pada tahun 1979. Keputusan itu menegaskan NU bertujuan untuk menegakkan syariat Islam menurut paham Aswaja, yaitu ahli Madrabib Alarba'ah, dan mengusahakan berlakunya ajaran Aswaja dalam masyarakat. Lihat juga Anggaran Dasar dan Anggaran Rumah Tangga NU 1979 pasal 2 ayat 1. 2008), 24.

9 As'ad Said Ali, Pergolakan di Jantung Tradisi: NU yang Saya Amati Jakarta: LP3ES, 
Hampir seluruh pesantren NU memberikan dasar pengajaran ini. Aliran tarekat secara umum sangatlah beragam, tetapi yang memiliki keterkaitan dengan NU adalah aliran yang dianggap mu'tabaroh dan mempunyai sanad sampai kepada Nabi Muhammad Saw., seperti Qadiriyyah, Naqsabandiyah, Syatariyah, Tijaniyah, dan Rifaiyah. ${ }^{10}$ Para jemaah pengikut tarekat tersebut meyakini akan mendapatkan syafaat dari para mursyid masing-masing yang secara hirarkis sampai kepada Rasulullah Saw.

Cabang-cabang tarekat tersebut, umumnya menginduk kepada pemikiran Imam Junaid Albaghdadi. Posisi Albaghdadi dalam dunia tarekat sangatlah tinggi, berkat keberhasilannya menemukan titik temu antara pemikiran radikal dan liberal tasawuf yang dikembangkan Abu Yazid Albustami $(875 \mathrm{H})$ dan Husein ibn Manshur Alhallaj $(928 \mathrm{H}) .{ }^{11}$ Kedua tokoh ini mendeskripsikan pemikirannya hingga menafikan realitas konkret manusia, sebagaimana tercermin dalam doktrin ittihad, bulul, dan wabdah alwujud. Manurut Albaghdadi, tasawuf itu harus tetap berpijak pada realitas konkret manusia. Pencapaian tertinggi dunia tasawuf hanya sampai pada level mahabbah dan ma'rifat, dan syariat tetap menjadi hal penting untuk menuju mababbah dan ma'rifat. ${ }^{12}$ Atas dasar inilah gagasan Albaghdadi dikenal cocok dan sesuai dengan pemikiran ahli hadith dan ahli fikih, sehingga ia dikenal sebagai tokoh yang berhasil 'mendamaikan' ketegangan antara fikih dan tasawuf.

Titik temu antara teologi Alasy'ari, sufisme Albaghdadi, dan Madzahib Alarba'ah selanjutnya menjadi infrastruktur penting bagi paradigma keislaman NU. Melalui komponen inilah paradigma keislaman NU dibangun atas tiga pilar utama, yaitu: pertama, dalam dimensi teologi, NU menganut paham ablussunnah wa aljama'ah sesuai dengan konsep yang

10 Martin van Bruinessen, Kitab Kuning, Pesantren, dan Tarekat (Bandung: Mizan, 1995), 123.

11 M. Ali Haidar, Nabdlatul Ulama dan Islam di Indonesia: Pendekatan Fikih dalam Politik. (Jakarta: Gramedia, 1998), 77.

12 M. Ali Haidar, Nahdlatul Ulama dan Islam di Indonesia: Pendekatan Fikih dalam Politik, 77. 
dibangun oleh Imam Abu Hasan Alssy'ari dan Imam Manshur Almaturidi; kedua, dalam dimensi fikih, NU mengikuti salah satu dari Imam madzhab fikih yang empat, yakni Abu Hanifah Alnu'man, Imam Malik ibn Anas, Imam Muhammad ibn Idris Alsyafi'i, dan Imam Ahmad ibn Hanbal; ketiga, dalam dimensi tasawuf, NU mengikuti Imam Alghazali dan Imam Junaid Albaghdadi. ${ }^{13}$

\section{Genealogi Revolusi Paradigma Keislaman}

Salah satu fenomena menarik pasca khittah 1926 adalah terjadinya revolusi paradigma keislaman NU, yang sebelumnya dianggap mapan tanpa kritikan. Keinginan untuk mengembangkan kaitan yang lebih relevan antara agama dan kehidupan sosial di era postmodern telah memotivasi para pemikir di kalangan NU untuk mencari pendekatan baru yang lebih transformatif untuk mengevaluasi pemikiran keagamaan, khususnya yang berkaitan dengan persoalan teologi keislaman (ablussunnab wa aljama'ab) sebagai worldview-nya, wacana fikih realitas yang lebih kontekstual, kajian kritis atas kitab-kitab mu'tabar, dan berbagai kajian sosial dan ekonomikerakyatan.

Genealogi lahirnya gagasan revolusioner di ranah paradigma keislaman NU tidak lepas dari dialektika internal dan sentuhan eksternal yang melingkupi perjalanan sejarah NU. Martin Van Bruinessen, seorang pemerhati gerakan organisasi sosial-keagamaan menjelaskan keadaan NU setelah keluar dari zona politik praktis. Menurutnya, poin utama yang menjadi embrio lahirnya revolusi paradigma keislaman NU adalah kbittah 1926. Saat NU kembali menjadi jam'iyyah diniyah, dikalangan generasi mudanya terlihat dinamika baru yang ditandai dengan dominasi aktivitas sosial-intelektual yang nyaris tidak tertandingi oleh komunitas lain. ${ }^{14}$

Tesis Martin mengenai dominasi aktivitas sosial-intelektual itu dibenarkan oleh Rumadi yang mengamati perkembangan sosial-intelektual

13 As'ad Said Ali, Pergolakan di Jantung Tradisi: NU yang Saya Amati, 29-30.

14 Penjelasan lebih komprehensif, lihat Martin Van Bruinessen, NU: Tradisi, Relasi-Relasi Kuasa, Pencarian Wacana Baru (Yogyakarta: LKiS, 1999). 
di lingkungan NU. Menurutnya, dominasi aktivitas sosial-intelektual di lingkungan NU merupakan akibat dari melesatnya laju mobilitas sosial-intelektual di internal NU yang belum pernah terjadi semenjak kelahirannya. Mobilitas sosial-intelektual di lingkungan NU sendiri terjadi pada paruh kedua dekade 70-an dan klimaksnya pada awal dekade 80-an. Tesis ini dibuktikan dengan banyaknya santri NU yang tidak hanya menjadi penghuni setia pesantren, tetapi mulai memenuhi kuota mahasiswa di Perguruan Tinggi. ${ }^{15}$

Berdirinya IAIN di Indonesia memperlebar jalan santri meraih pendidikan tinggi. Tradisi akademik seperti diskusi, akulturasi, dan interaksi sosial dari berbagai varietas serta luasnya bacaan membantu mereka memperluas cakrawala sosial dan pemahaman intelektual. ${ }^{16}$ Seiring dengan itu, generasi NU yang mengalami urbanisasi intelektual pun semakin intens bersentuhan dengan ilmu-ilmu modern yang tidak pernah diperolehnya di pesantren. ${ }^{17}$ Konsekuensi logis atas fenomena itu adalah terjadi pergeseran cara pandang terhadap ajaran dan terjadi diversi pemikiran yang berimplikasi pada upaya untuk mengadaptasi dogma keNU-an dengan tuntutan perubahan sosial yang berasal dari luar. ${ }^{18}$

15 Rumadi, Post Tradisionalisme Islam: Wacana Intelektualisme dalam Komunitas NU (Cirebon: Fahmina Institute, 2008), 105.

16 Laode Ida, NU Muda: Kaum Progresif dan Sekularisme Baru (Jakarta: Erlangga, 2004), xiv.

17 Semenjak kelahirannya, NU dianggap sebagai organisasi konservatif yang hanya menjadi "penjaga gawang" ortodoksi dan minus wacana pemikiran, sehingga epistemologi pemikiran keagamaannya dianggap sebatas daur ulang ijtihad (taqlid). Dalam istilah ekstrem pembaharuan pemikiran Islam secara prinsip bertentangan dengan pandangan keagamaan NU. Bahkan sebagian besar ulama NU pada akhir dekade 70 -an masih alergi terhadap apa yang mereka definisikan sebagai Barat. Artinya, mereka belum bersentuhan-kalaupun bersentuhan mereka mengambil posisi defensif-dengan "ilmuilmu sekuler" yang digunakan sebagai "pisau analisis" terhadap ajaran keagamaannya. Azyumari Azra mengelompokkan tiga tipe sikap kaum muslimin ketika vis a vis dengan Barat, yaitu sikap apologetik, identifikatif, dan afirmatif. lihat. Azyumardi Azra, Pergolakan Politik Islam: dari Fundamentalisme, Modernisme, hingga Postmodernisme (Jakarta: Paramadina, 1996), iii-iv. 110.

18 Rumadi, Post Tradisionalisme Islam: Wacana Intelektualisme dalam Komunitas NU, 
Dialektika internal yang juga menjadi sebab terjadinya revolusi paradigma keislaman NU adalah adanya figur lokomotif yang berperan langsung di level struktural NU, yang pemikirannya mampu menjembatani jurang antara tradisionalisme dan modernisme (liberalisme). Disamping memiliki wawasan tradisionalme keislaman yang baik, ia juga telah mengalami transformasi ilmu pengetahuan yang cukup progresif, lantaran kerap bersentuhan dengan khazanah tradisi luar. ${ }^{19}$ Tokoh tersebut adalah Abdurrahman Wahid (Gus Dur, 1940-2009) yang layak disebut sebagai bapak revolusi paradigma pemikiran keislaman NU. Kehadirannya, sebagaimana dicatat oleh Syafiq Hasyim dan Robin Bush memiliki arti sangat penting bagi pembaharuan pemikiran NU.

“........kepemimpinan Gus Dur menjadi kunci dibukanya gerbang intelektualisme kalangan NU. Gus Dur mengambil dua langkah penting sejak menjadi elit struktural NU. Pertama, ia menyesuaikan posisi NU dengan posisi kembali ke kbittah 1926, menarik NU dari kegiatan politik struktural. Kedua, Gus Dur melakukan penyesuaian posisi teologi, fikih, dan tasawuf dalam kerangka Ablussunnah wa Aljamaah. Melalui sejumlah tulisannya Gus Dur juga mengkritik doktrin keagamaan NU dan mendorong intelektual muda NU untuk lebih intensif mewujudkan kritik-kritiknya. ${ }^{20}$

Perkembangan pesat yang terjadi di internal NU pasca khittah 1926 juga dimungkinkan oleh hasil sentuhan eksternal yang mampu mengurangi isolasi kaum santri. Pertama, selain kemunculan Perguruan Tinggi Keagamaan Islam Negeri (PTKIN) yang terus mengecambah, adanya proyek pengembangan masyarakat melalui pesantren yang dipelopori oleh Lembaga Penelitian, Pendidikan, dan Penerangan Ekonomi dan

19 Ahmad Rizky Mardhatillah Umar, "A Genealogy of Moderate Islam: Governmentaly and Discourses of Islam in Indonesia's Foreign Policy," Studia Islamika 23, no. 3 (2016): 414-418.

20 Syafiq Hasyim dan Robin Bush, "NU and Discourses: Islam, Gender Right, and Traditional Islamic Society," in Conference on Islam, Civil Society, and Development in Southeast Asia (Melbourne: University of Melbourne, 1998). Lihat juga Djohan Effendi, Pembaruan tanpa Membongkar Tradisi (Jakarta: Kompas, 2010), 9-10. 
Sosial (LP3ES), ${ }^{21}$ dan hal ini melibatkan sejumlah LSM nasional maupun internasional sepertihalnya FriedrichNaumannStiftung(FNS) dan Netherlands Organization for Internationa Assistance (Nvib). Akibatnya, pesantren mulai ditarik dalam jaringan komunikasi internasional. Sementara pasca Muktamar di Situbondo, generasi muda NU sendiri mulai terlibat langsung dalam berbagai aktivitas LSM, khususnya Perhimpunan Pengembangan Pesantren dan Masyarakat (P3M) pada tahun 1983 yang secara khusus mengakomodir pengembangan masyarakat melalui pesantren. ${ }^{22}$

Kedua, kemunculan gerakan intelektualisme progresif di belahan dunia Arab, seperti Nasr Hamid Abu Zayd, Hassan Hanafi, Muhammad Syahrur, Muhammad Abed Aljabiri, Fatimah Mernissi, dan lainnya yang turut memberi inspirasi terhadap lompatan tradisi intelektualisme NU. Intervensi pemikiran dari luar ini dipandang penting untuk memperbaiki kultur domestik yang tertinggal. ${ }^{23}$ Pendapat ini diperkuat oleh Ahmad Baso saat melakukan pelacakan terhadap genealogi post-tradisionalisme NU:

"Kemunculan karya-karya Muhammad Abid Aljabiri di Indonesia menandai fase berikutnya, dari fase awal yang dirintis oleh Abdurrahman Wahid. Jika pemikiran Abdurrahman Wahid memulai gerakan post-tradisionalismenya dengan sejumlah gagasan dan ideide, maka di tangan Aljabiri fase berikutnya ditandai dengan proses pengisian proyeksi metodologi dan epistemologinya. Itulah yang diapresiasi teman-teman dari NU. Karena fase Abdurrahman Wahid ini, termasuk di antaranya Hassan Hanafi dan Fatima Mernissi adalah pengayaan dari ide-ide dalam pemikiran dan aksi politik,

21 Proyek pengembangan masyarakat melalui pesantren kemudian mengilhami terbentuknya sejumlah LSM afiliasi kultural NU di berbagai daerah di Indonesia seperti LKiS di Yogyakarta, eLSAD di Surabaya, Lakpesdam di Jakarta, Averos di Malang, INCReS di Bandung, The Wahid Institute di Jakarta, Fahmina Institut di Cirebon, dan lain-lain. lihat Martin Van Bruinessen, NU: Tradisi, Relasi-Relasi Kuasa, Pencarian Wacana Baru, 235-257.

22 Martin Van Bruinessen, NU: Tradisi, Relasi-Relasi Kuasa, Pencarian Wacana Baru, 235-257.

23 Rumadi, Post Tradisionalisme Islam: Wacana Intelektualisme dalam Komunitas NU, 119-120. 
seperti nasionalisme, pribumisasi, sekularisasi, dan feminisme. Sementara fase yang dikenal kini dari Aljabiri, Muhammad Arkoun, dan Nasr Hamid Abu Zayd adalah fase metodologis dari posttradisionalisme Islam". ${ }^{24}$

Dari beberapa tokoh yang disebut itulah dapat disimpulkan bahwa orientasi intelektualisme post-tradisionalisme NU banyak dipengaruhi oleh pemikir Islam kontemporer. Meski secara ekstrinsik tidak dijelaskan keterkaitan secara metodologis antara pemikiran Gus Dur dan Aljabiri dalam mempengaruhi metodologi pemikiran kaum muda NU, namun bentuk apresiasi yang kuat terhadap wacana pemikiran keislaman kontemporer itu tampak sekali menjadi corak epistemologinya.

Senada dengan Baso, Laode Ida mengemukakan lebih rinci genealogi yang mempengaruhi munculnya kelompok NU progresif, yaitu: Pertama, adanya dinamika internal dan benturan di jantung tradisi NU yang terjadi akibat semakin banyaknya kaum muda NU (alumni pesantren) yang masuk ke Perguruan Tinggi modern. Hal ini menjadikan mobilitas sosialintelektual di kalangan kaum muda NU semakin tinggi. Akibatnya, terjadi diversifikasi pemikiran dan perkembangan pemikiran yang berhadapan dengan tradisi komunitasnya sendiri. ${ }^{25}$

Kedua, tuntutan modernisasi sebagai konsekuensi globalisasi. Modernisasi yang mencengkeram semua aspek kehidupan-dengan segala kelebihan dan kekurangannya-membuka kesadaran bahwa NU harus merespon berbagai perkembangan itu, meskipun harus mengalami benturan tradisi yang telah mengakar. Dalam dunia pendidikan misalnya, arus modernisasi memaksa NU melakukan penyesuaian terhadap polarisasi modernitas. Akibatnya, pesantren sebagai 'balai konservasi' tradisi keislaman klasik harus menyesuaikan dengan sistem pendidikan yang lebih terstruktur. Demikian juga di bidang manajemen organisasi, NU dituntut menata ulang organisasi sesusai dengan prinsip modern.

${ }^{24}$ Ahmad Baso, "Neo-Modernisme Islam vs Post-Tradisionalisme Islam," Jurnal Tashwirul Afkear 10, no. 1 (2001): 32.

25 Laode Ida, NU Muda: Kaum Progresif dan Sekularisme Baru, 160. 
Ketiga, kerisauan terhadap perkembangan sosial-politik. Kerisauan ini muncul lantaran keberadaan NU sangat dipengaruhi oleh perkembangan politik. Bahkan bentuk perubahan sikap NU terhadap negara merupakan refleksi atas perubahan politik. Keempat, perkembangan gerakan demokratisasi dan penegakan HAM di belahan dunia yang dianggap sebagai agama baru dunia internasional. Hal ini tidak dapat dipandang parsial oleh NU. Sehingga NU dituntut untuk merajut ulang doktrin keagamaan dan tradisinya atas berbagai perkembangan itu. Dari sinilah dapat dipahami mengapa program LSM berkultur NU getol membahas tema seputar demokrasi, HAM, gender, dan civil society. Hal ini menunjukkan bahwa NU serius melakukan akselerasi atas tradisi dan pembaharuan wacana yang berkembang. ${ }^{26}$

Dari sinilah telihat jelas munculnya lapisan masyarakat kritis di tubuh NU yang dipengaruhi oleh banyak faktor. Proses mempertautkan antara doktrin keagamaan dan pemahaman pengetahuan telah mendorong mereka untuk melakukan koreksi, evaluasi, refleksi, dan terus-menerus mencari jalan pencerahan, dan merespon perubahan yang lebih relevan. Tradisi ini pada gilirannya mampu menumbangkan paradigma lama yang dianggap sudah kadaluarsa, digantikan oleh paradigma keislaman baru yang lebih relevan dengan dinamika perubahan.

\section{Revolusi Paradigma Pemikiran Keislaman}

\section{Aswaja sebagai Manhaj Alfikr; Paradigma Teologi Baru dalam NU}

Wacana mencari paradigma teologi baru dalam NU muncul ketika Said Aqil Siradj menjabat sebagai Naib Katib ${ }^{27}$ Syuriah PBNU mempertanyakan kembali definisi ablussunnah wa aljama'ah yang lazim dipahami kalangan nabdliyin. ${ }^{28}$ Meski demikian, jauh sebelum Said Aqil

${ }^{26}$ Laode Ida , NU Muda: Kaum Progresif dan Sekularisme Baru, 160-202.

27 Naib Katib berarti wakil sekretaris dalam lembaga Syuriah PBNU.

${ }^{28}$ Ungkapan itu pertama kali disampaikan oleh Said Aqil Siradj dalam ceramah yang disampaikan dalam forum PMII pada 23 April 1995 di Bangil, Jawa Timur. Ceramah 
menggugat itu, Gus Dur secara implisit telah mengawali kritiknya terhadap pandangan teologi NU (Aswaja) yang hanya dipahami sebagai sebuah dogma yang keabsahannya dianggap bersifat final.

Dalam perspektif Gus Dur, gagasan Asy'ari dan Maturidikemudian menjadi ablussnunnah wa aljama'ah—seharusnya tidak dipahami sebagai dogma kaku yang mengikat begitu saja, tetapi ditransformasikan dalam konteks masyarakat secara luas. Transformasi ini meliputi pandangan tentang manusia, tentang ilmu pengetahuan dan teknologi, tentang ekonomi, pengaturan kehidupan, tentang hubungan individu dan masyarakat, tentang tradisi dan dinamisasinya, tentang cara-cara pengembangan kehidupan masyarakat dan tentang asas-asas internalisasi dan sosialisasi yang dapat dikembangkan dalam konteks doktrin formal yang dapat diterima saat ini. ${ }^{29}$

Transformasi pandangan-pandangan di atas menunjukkan bahwa Gus Dur hendak menggeser perdebatan teologi yang spekulatif menjadi perdebatan yang lebih aplikatif. Gagasan Gus Dur inilah yang kemudian dilanjutkan oleh Said Aqil Siradj dengan memaparkan realitas sejarah, bagaimana kaum nabdliyyin memahami Aswaja yang keliru secara konseptual. Ia mengatakan:

“Terminologi ablussunnab wa aljama'ab sesungguhnya sederhana, singkat, dan tidak asing di telinga kita—diakui atau tidak—masih banyak mengandung kesalahan persepsi. Sebagian memahami aswaja identik dengan "Islam". Sebagian yang lain hanya melihat Aswaja sebagai "madzhab". Ada pula yang mengartikan Aswaja sebagai karakteristik komunitas kaum muslimin yang mengamalkan aktivitas tertentu, seperti tablilan, selamatan, berjanjenan, dan qunut. Bahkan ada yang mamakai term Aswaja sebagai langkah "purifikasi" ajaran Islam (alishlab aldiin). ${ }^{30}$

Said Aqil itu kemudian dimuat dalam majalah "Aula" dan diterbitkan menjadi buku "Ahlussunnah wal-Jama'ah dalam Lintasan Sejarah."

29 Abdurrahman Wahid, Islam Kosmopolitan: Nilai-Nilai Keindonesiaan dan Transformasi Kebudayaan (Jakarta: The Wahid Institute, 2007), 32-43.

30 Said Aqil Siradj, Ablussunnah dalam Lintasan Sejarah (Yogyakarta: LKPSM, 1997), 6.

AL-A'RAF - Vol. XV, No. 2, Juli - Desember 2018 
Lebih jauh, Said Aqil menjelaskan fakta yang secara eksplisit menawarkan ajakan melakukan reformulasi dan reinterpretasi Aswaja yang meliputi (a) Aswaja seharusnya tidak jumud, ketat, eksklusif, elitis, dan mempertahankan satus quo. Gagasan Alssy'ari muncul untuk mencari jalan tengah di antara dua kutub ekstrem; skripturalisme ahli hadith dan rasionalisme Muktazilah. Teologi Asy'ariyah tidak bebas dari kelemahan, Ibn Taimiyah melakukan koreksi, Muhammad Abduh pun melakukan hal yang sama terhadap Ibn Taimiyah, begitu seterusnya. (b) Aswaja bukanlah madzhab, tetapi metode berpikir yang mendasari beberapa pemikiran dan madzhab. Madzhab-madzhab tersebut sangat lentur, netral, moderat, toleran, dan berimbang. Hal ini ditunjukkan oleh sikap Sunni yang mendahulukan wahyu, tetapi disaat yang sama memberi ruang luas terhadap akal. Oleh karena itu, ia tidak ekstrem dan tidak menganggap selain kelompoknya kafir berkenaan dengan seluruh aspek kehidupan, keyakinan, muamalat, akhlak, sosial, politik, dan budaya. (c) Aswaja yang tidak mempunyai konsep jelas tentang imamah, dianggap cenderung pragmatis dan menekankan lebih kepada realitas ketimbang substansi. Akan tetapi hal ini justru membuatnya mudah menerima situasi. Dari segi sejarah perumusannya, Aswaja adalah proses kelanjutan dari konseptualisasi Alasy'ari setelah mengikuti Mu'tazilah selama puluhan tahun, dan tetap dilanjutkan oleh Imam Albaqillani dan Imam Juwaini, menolak filsafat dan menerima tasawuf yang dirumuskan Alghzali. ${ }^{31}$

Pergulatan pemikiran Islam di kalangan NU mengenai reformulasi Aswaja ternyata tidak hanya terjadi di kalangan NU tanah air, kritik serupa juga pernah dilontarkan oleh kalangan mahasiswa NU yang sedang belajar, sekaligus menjadi Pengurus Cabang Istimewa NU (PCINU) Mesir. Mereka menggelar halaqoh dan mendiskusikan isu-isu keislaman perspektif teologi pembangunan. Adalah Nadjib Buchori, satu dari sekian banyak mahasiswa NU yang menempuh pendidikan di Kairo, pernah memberikan materi fundamental mengenai kelemahan teologi Asy'ariyah. Ia menulis:

31 Djohan Effendi, Pembaruan tanpa Membongkear Tradisi, 65-67. 
“...Asy'ari mampu memberi gambaran utuh tentang kekuasaan Tuhan, tetapi gagal menjelaskan fenomena keteraturan alam yang diciptakan-Nya. Kepastian hukum alam dalam perspektif Asy'ari menjadi kabur, dan ini melemahkan semangat rasionalitas. Sebab, pengingkaran terhadap adanya kausalitas dalam keteraturan alam berarti mengebiri fungsi akal. Pada perkembangan selanjutnya, doktrin tersebut diintegrasikan dengan tasawuf yang dipahami mayoritas Sunni sebagai metode menjauhkan diri dari keduniaan. Akibat doktrin dogmatis itu, pandangan teologi kaum Sunni lebih banyak berorientasi eskatologis. Kegairahan intelektual dan penelitian rasional menjadi lenyap digantikan oleh kegiatan keilmuan yang terbatas pada lingkup pemikiran salaf. Singkatnya, manusia yang fitrahnya dinamis menjadi statis akibat pandangan keagamaan yang irrasional, fatalis, dogmatis, dan hanya berorientasi eskatologis". ${ }^{32}$

Atas kritiknya itu, Buchori menawarkan pandangan alternatif mengenai doktrin teologi Aswaja yang dianggapnya fatal itu. Menurutnya, perlu paradigma teologi baru bagi kaum Sunni agar dapat tercipta pandangan keagamaan yang progresif. Hal ini dapat dilakukan dengan menggali warisan intelektual yang pernah ditelurkan para ulama Aswaja. Untuk menumbuhkan rasionalitas, Buchori menawarkan gagasan Alrazi sebagai alternatif. Sebab rasionalitas yang digagas Alrazi tidak mengingkari kausa prima, sehingga akal tidak dipaksakan menembus wilayah kekuasaan Tuhan. Rasionalitas yang tumbuh dari pemikiran Alrazi pada gilirannya mampu melepaskan manusia dari tradisi pemikiran yang didogmakan. ${ }^{33}$

Sementara mengenai kebebasan manusia dalam menentukan nasibnya, pemikiran Mahmud Syaltut, Ibnu Taimiyah, dan Aljuwaini dapat dijadikan sebagai alternatif. Dengan meyakini qadla dan qadar seperti digambarkan Mahmud Syaltut, manusia terhindar dari sikap fatalistis yang pada gilirannya menghindarkannya dari pandangan keagamaan yang hanya

32 Moh. Najib Buchori, "Aqidah Aswaja dan Pembangunan Manusia: Upaya Menemukan Aqidah Alternatif bagi Kebangkitan Umat Islam," Nuansa: Jurnal Kajian Keislaman Keluarga Mabasiswa Nabdlatul Ulama Cabang Mesir, no. 1 (1997): 3.

33 Moh. Najib Buchori, "Aqidah Aswaja dan Pembangunan Manusia: Upaya Menemukan Aqidah Alternatif bagi Kebangkitan Umat Islam”, 6. 
mementingkan eskatologi. Jika keyakinan semacam ini berkembang, maka teologi Aswaja dapat menjadi teologi pembangunan, pembebasan, dan keseimbangan di masa mendatang. ${ }^{34}$

Terlepas dari misi teologi pembebasan di atas, agenda mendesak yang menuntut segera dirumuskan di era postmodern adalah merespons persoalan hubungan Islam dengan Negara yang sudah terkotak dalam nation state; hubungan syari'ah dengan hukum publik, nasional maupun internasional; pemberdayaan rakyat menuju masyarakat musyawarah dan terbebas dari belenggu penghambaan; serta konsep keadilan ekonomi, politik, dan hukum". ${ }^{35}$ Di sinilah pentingnya NU merespons berbagai persoalan di era postmodern itu. Dengan memahami Aswaja sebagai manhaj alfikr, manusia lebih mudah menerima hal-hal baru selama diyakini benar dan tidak ragu membuang hal-hal lama jika terbukti salah. ${ }^{36}$

Menyikapi ramainya wacana mencari teologi baru perspektif NU yang memunculkan sejumlah reaksi positif sekaligus resistensi negatif itu, melalui forum halaqoh di Jakarta pada 21-22 Oktober 1996, PBNU mengundang Dawam Anwar, Said Aqil Siradj, dan Noerhadi Iskandar Albarsany sebagai pembicara mencari rumusan teologi Aswaja perspektif NU. ${ }^{37}$

Terdapat perbedaan mendasar terkait pemahaman Aswaja antara Dawam Anwar dan Said Aqil Siradj. Dawam memahami Aswaja dengan pendakatan normatif. Aswaja dipahami sebagai dogma yang sama universalnya dengan Islam. Menurutnya, meragukan kemampuan Aswaja dalam menghadapi tantangan masa depan sama halnya meragukan kemampuan Islam itu sendiri. Sementara Said Aqil Siradj memahami

34 Moh. Najib Buchori, "Aqidah Aswaja dan Pembangunan Manusia: Upaya Menemukan Aqidah Alternatif Bagi Kebangkitan Umat Islam”, 6.

35 Imam Ghazali, "Aswaja Klaim Nahdlatul Ulama: Pembakuan terhadap Kemapanan dalam Visi Anak Muda Nahdlatul Ulama," Nuansa: Jurnal Kajian Keislaman Keluarga Mahasiswa Nabdlatul Ulama Cabang Mesir, no. 1 (n.d.): 4.

36 Gagasan ini menjadi rasional ketika dikaitkan dengan prinsip dasar tradisi berpikir NU, yaitu "almuhafadzah 'ala qadim alshalih wa alakhdzu bi alljadid alaashlah." lihat. As'ad Said 'Ali, Pergolakan di Jantung Tradisi: NU Yang Saya Amati, 38.

37 Djohan Effendi, Pembaruan tanpa Membongkar Tradisi, 271-272. 
Aswaja melalui pendekatan historis. Beliau mendefinisikan Aswaja sebagai metode berpikir yang didasarkan pada sumber utama (Alqur'an dan Sunnah), bukan madzhab teologi yang bersifat final seperti dipahami oleh banyak kalangan NU, tetapi sebagai bagian dari proses memahami ajaran Islam.

Sementara Noerhadi yang menjadi pembicara terakhir merumuskan konsepsi Aswaja dengan mengambil jalan tengah. Ia memperluas konsep bermadzhab dengan tidak hanya dalam bentuk qauly, tetapi juga manhajy. Beliau membedakan antara Islam sebagai cita-cita ideal dengan Islam sebagai kenyataan historis. Menurutnya, Aswaja hendaknya didekati dari persoalan kedua. Namun, halaqob akhirnya sepakat dengan rumusan seperti yang tertera dalam sebuah hadith Nabi yang mengatakan, bahwa Aswaja adalah "orang-orang yang mengikuti jalan yang diamalkan oleh Nabi Saw. dan Sahabat r.a dan berpegang kepadanya."

Said Aqil Siradj sendiri telah mengusulkan rumusan Aswaja sebagai manhaj alfiker aldini alsyamil 'ala syu'uni alhayat wa muqtadhayatiha alqa'im 'ala asasi altawasuth wa altawazun wa ali'tidal wa altasamuh (metode berpikir keagamaan yang mencakup segala aspek kehidupan dan berdiri di atas prinsip jalan tengah, seimbang, moderat, dan toleran). Meski awalnya gagasan Said Aqil Siradj belum mendapat respons dari peserta halaqoh, namun lambat-laun rumusan tersebut diterima menjadi rumusan baku, definisi Aswaja perspektif NU; yaitu teologi Aswaja sebagai manhaj alfiker. Sebuah paradigma baru teologi dalam NU. ${ }^{38}$

\section{Tradisi Fikih NU: dari Qauly ke Manbajy}

Fikih, dalam kenyataannya merupakan kitab perilaku manusia yang dituntut secara operasional-fungsional sesuai dengan kondisi geografis dan demografis. Sebagai al'ilmu bi alabkam alsyar'iyyah alamaliyyah almuktasab min adillatiha altafshiliyyah' (pengetahuan tentang hukum syariah amaliah yang digali dari petunjuk-petunjuk yang bersifat global), fikih memiliki peluang luas untuk berkelindan dengan perkembangan zaman. Artinya, definisi fikih sebagai sesuatu yang digali menumbuhkan pemahaman

38 Djohan Effendi, Pembaruan tanpa Membongkear Tradisi, 271-272. 
bahwa fikih lahir melalui serangkaian proses sebelum akhirnya dinyatakan sebagai hukum praksis. Proses penggalian hukum yang biasa dikenal dengan ijtihad ini bukan saja memungkinkan adanya perubahan, tetapi juga pengembangan tidak terhingga terhadap berbagai aspek kehidupan yang terus mengalami perkembangan.

Dengan demikian, derasnya perubahan sosial yang dibarengi pesatnya ilmu pengetahuan menuntut adanya panduan rubaniah yang memiliki relevansi dengan nilai kebudayaan. Di sini, seharusnya fikih tidak dipahami sekadar alat untuk melihat peristiwa dari kacamata teologis semata, tetapi aspek sosiologis-antropologis patut menjadi paradigma pemaknaan agar produk hukum yang dihasilkan sesuai dengan konteks perkembangan. Apabila fikih gagal melayani kebutuhan pokok sesuai dengan konteks keadaan manusia yang dinamis, maka manusia akan semakin jauh dari kesadaran transendental. Oleh karena itu, paradigma fikih harus ditempatkan dalam konteks memecahkan permasalahan, yaitu paradigma yang dibangun berdasarkan pemenuhan kebutuhan yang sejalan dengan maqasid syari'ah.

Menyoal wacana fikih perspektif NU, rujukan utama fikih NU adalah kepustakaan fikih Syafi'iyah, sesuai dengan anutan mayoritas umat Islam di Indonesia. Madzhab ini dianggap paling sesuai dengan kondisi sosial-budaya masyarakat Indonesia. Tradisi intelektual yang terbingkai dalam tradisionalisme madz̧habiyah telah membentuk pemikiran keagamaan yang berorientasi pada fikih sebagai cara pandang. Fikih dikembangkan sebagai seni mempengaruhi pola keberagamaan. Akibatnya, pengaruh fikih itu—meski akidah dan tasawuf juga merupakan aspek utama pengetahuan keislaman yang satu sama lain terkait erat bagi tradisionalis, tetapi fikih dianggap sebagai sayyid alul'ulum (tuan ilmu pengetahuan) telah membentuk pola pikir yang cenderung normatif-legalistik. ${ }^{39}$

Kedudukan khusus atas fikih ini terkait erat dengan sifat fikih sebagai pelajaran agama Islam yang mencakup seperangkat aturan yang berkaitan

39 Kecenderungan ini tampak jelas ketika umat Islam menghadapi kasus-kasus baru, baik peristiwa maupun benda. Pernyataan pertama yang timbul dalam pikiran mereka adalah apa hukum hal tersebut, diperbolehkan atau dilarang, halal atau haram. lihat. Djohan Effendi, Pembaruan tanpa Membongkar Tradisi, 155. 
dengan ibadah mabdhah dan ibadah muamalah yang paling relevan dengan kehidupan sehari-hari. Bahkan kiai Sahal Mahfudz menggambarkan bahwa fikih telah diperlakukan oleh sebagian umat Islam sebagai "norma dogmatis yang tidak dapat diganggu gugat. Tidak jarang fikih-dalam hal ini kitab kuning-kerap dianggap sebagai 'kitab suci kedua' setelah Alqur'an. ${ }^{40}$

Dalam melegitimasi produk hukum, NU memiliki tradisi babtsul masa'il sebagai forum tertinggi, di bawah pengelolaan lembaga Syuriah yang berfungsi sebagai pembahasan persoalan-persoalan tematik keagamaan; almasa'il aldiniyah dan almasa'il alfiqhiyah. ${ }^{41}$ Adapun produktivitas fikih NU bersumber dari telaah skripturalisme trialektika tiga "kitab suci" yang dianggap paling sahih untuk dijadikan sebagai sumber dalam proses legalitas hukum. Ketiga hal tersebut dalam urutannya adalah Alqur'an, Alhadith dan Qaul (pendapat ulama yang terdapat dalam kitab-kitab klasik yang muktabar). ${ }^{42}$ Sementara dalam menetapkan fatwa, proses pencarian hukum suatu kasus di NU masih dikupas secara tradisionalisme madz̧habiyah, yaitu melalui metode qauly.

Sayangnya, dalam praktik penggalian hukum, NU selalu memulainya dengan penelusuran kitab kuning terlebih dahulu. Alqur'an dan Alhadith hanya digunakan sebagai catatan "legitimasi teologis" semata atas ide-ide keislaman yang terdapat dalam kitab kuning. Bahkan tidak jarang, Alqur'an dan Alhadith hanya digunakan sebagai "catatan kaki". ${ }^{43}$ Dalam realitas inilah suara kritis datang dari generasi muda NU, menuntut pemaharuan ke arah fikih realitas bermunculan.

${ }^{40}$ Sahal Mahfudz, Nuansa Fikih Sosial (Yogyakarta: LKiS, 1994), 21.

41 Djohan Effendi, Pembaruan tanpa Membongkar Tradisi, 156.

42 Kitab-kitab muktabar sebagaimana dimaksud adalah kumpulan kitab-kitab klasik (kitab kuning) yang telah mengalami uji kelayakan melalui filterisasi kitab-kitab yang sesuai dengan doktrin ablussunnah wa aljama'ah. Adapun kitab-kitab yang dianggap muktabar biasanya diidentikkan dengan kitab fikih bergenre syafi'iyah. Lihat. Husein Muhammad, Altsimar Alyani'ah fi Riyadh Albid'ah, Karya Syeikh Mubammad Nawawi Albantani (Cisarua, 1994), 158.

${ }^{43}$ M. Mukhsin Jamil, Nalar Islam Nusantara: Studi Islam ala Mubammadiyah, Alirsyad, Persis dan NU (Jakarta: Direktorat Pendidikan Tinggi Islam, 2007), 386. 
Mereka menyadari, bahwa di tubuh NU telah terjadi pengendapan ijtihad dalam memproduksi hukum yang datang belakangan, sehingga terjadi kejumudan pemikiran. Apa yang menjadi keinginan mereka adalah menggerakkan kembali tradisi ijtihad seperti pernah dilakukan oleh ulama terdahulu. ${ }^{44}$ Bermadzhab tidak harus mengikuti produk ijtihad ulama madzhab (qauly), tetapi mengikuti metode berpikir ulama madzhab adalah bagian dari bermadzhab (manhajy). Dengan demikian, kitab kuning seharusnya diterjemahkan sesuai kaidah penalaran, dipahami sesuai latar belakang, waktu, tempat, dan kepentingan penulisnya. Sehingga, kitab kuning menjadi kontekstual-operasional mengikuti perubahan zaman.

Kritik sakralitas kitab kuning ternyata tidak datang dari intektual muda NU semata, melainkan juga dari para kiai NU bernalar progressif turut meramaikan wacana pembaruan pemikiran NU di bidang fikih. Kiai Sahal Mahfudh yang pernah menjadi Rais 'Aam NU menunjukkan kritisismenya dengan mengatakan beberapa kelemahan fikih NU:

"Kajian masalah hukum (bahtsul masa'i) di NU dalam banyak hal belum begitu memuaskan untuk keperluan ilmiah maupun sebagai upaya praktis menghadapi tantangan zaman. Salah satu sebabnya adalah keterikatannya yang hanya pada satu madzhab (Syafi'i). Padahal, dalam AD/ART NU ditegaskan bahwa NU menaruh penghargaan yang sama terhadap empat madzhab yang ada. Ketidakpuasan juga muncul akibat cara berpikir yang tekstual, yaitu dengan menolak realitas yang tidak sesuai dengan rumusan kitab kuning tanpa memberikan jalan keluar (manquf) yang sesuai dengan tuntunan kitab itu sendiri. Maka, kegiatan yang dilakukan oleh komisi babtsul masa'il NU masih memerlukan upaya peningkatan serius. Agar apa yang dilakukan dapat mencapai ijtihad meskipun hanya muqayyad sifatnya, bukan sekadar men-tathbiq (mencocokkan) kasus yang terjadi dengan referensi tertentu saja". ${ }^{45}$

Atas dasar kritik epistemologi terhadap nalar fikih yang tekstualis itu, kiai Sahal kemudian mendukung penuh untuk melakukan pendekatan

${ }^{44}$ Djohan Effendi, Pembaruan tanpa Membongkar Tradisi, 189.

45 Sahal Mahfudz, Nuansa Fikih Sosial, 42.

AL-A'RAF - Vol. XV, No. 2, Juli - Desember 2018 
kontekstual dalam melakukan pengkajian terhadap kitab kuning. Bagi kiai Sahal "gagasan yang demikian tidak terlalu berlebihan, mengingat bahwa pemahaman kontekstual itu bukan berarti meninggalkan dan menanggalkan fikih secara mutlak. Tetapi segala aspek prilaku kehidupan menjadi terjiwai oleh fikih secara konseptual dan tidak menyimpang dari rel fikih itu sendiri". ${ }^{46}$

Kritik senada dikemukakan oleh Abdul Malik Madany, seorang ulama muda NU kelahiran Madura. Madany mengkritik sumber hukum fikih supaya didasarkan pada pendekatan sejarah teks, agar dapat menciptakan kemungkinan adanya perubahan formulasi hukum yang lebih fleksibel dan dinamis. Madany menganggap bahwa sikap untuk mengambil formulasi kitab kuning tertentu sebagai rumusan final kitab fikih tidaklah relevan kecuali untuk pemula. Bagi mereka yang pengetahuannya lebih, mutlak dibutuhkan keberanian intelektual untuk membuat terobosan yang bertanggungjawab. Studi ushul fiqih dan qawa'id alfiqih, menurutnya, dapat mengatasi persoalan di atas. ${ }^{47}$

Aspek lain yang dianggap sebagai kelemahan yang mempengaruhi budaya intelektual ulama NU adalah orientasi keilmuan di pesantren. Seorang cendekiawan NU, Tolchah Hasan mengemukakan kritiknya terkait dengan orientasi keilmuan NU yang lebih menekankan pada studi yang diterapkan pada pengetahuan semacam fikih, tasawuf, dan ilmu-ilmu alat terutama nabwu dan sharaf. Di pihak lain, ilmu-ilmu yang berkaitan dengan pengembangan gagasan dan penajaman akal, seperti logika, filsafat, sejarah, bahasa, sejarah hukum Islam, qawa'id alfiqih, dan tafsir diabaikan. Keadaan ini kemudian berdampak pada kedangkalan fikih ketika dihadapkan pada realitas sosial, terutama perkembangan ilmu pengetahuan dan teknologi. ${ }^{48}$

46 Sahal Mahfudz, Nuansa Fikih Sosial, 22.

47 Abdul Malik Madany, "Posisi Kitab Kuning dalam Khazanah Keilmuan," dalam Pembaruan tanpa Membongkar Tradisi, ed. Djohan Efendi (Jakarta: Kompas, n.d.), 167-168.

${ }^{48}$ M. Tolchah Hasan, Metode Pengajian Kitab di Pesantren: Tinjauan Ulang Pesantren (Jakarta: P3M, 1989), 30. 
Sementara itu, Husein Muhammad juga mengkritik cara berpikir fikih NU yang tekstual. Secara implisit, ia mengakatakan bahwa kitab kuning tidaklah lepas dari latar belakang kontekstual dan merupakan kumpulan opini pribadi yang terkait dengan konteks ruang dan waktu. Ia mengatakan:

“...cara berpikir fikih yang tetap mempertahankan teks-teks kitab seperti apa adanya masih menjadi fenomena umum dan terus diikuti oleh kebanyakan masyarakat Muslim sejak berabad-abad lamanya dan sampai hari ini berlangsung di mana-mana. Bahkan, sebagian di antaranya ada yang membatasi pada produk-produk pemikiran ulama mujtabid tertentu dan menolak mujtahid lainnya. Parahnya, gugatan terhadap teks fikih dan upaya pembongkaran warisan intelektual klasik dipandang sebagai kesombongan intelektual yang menyalahi akar tradisi. Ini tentu sebuah hegemoni sekaligus ironi dalam perspektif pemikiran ilmiah. Lebih dari itu, sikap dan pandangan memapankan fikih seperti itu dengan sendirinya telah memperlakukan fikih sebagai ideologi, bahkan menyamakannya dengan teks-teks yang menjadi sumber asalnya, Alqur’an...”. ${ }^{49}$

Berdasarkan gagasan tersebut, pada tahun 1989 diselenggarakan halaqob alim ulama di pesantren Miftahul Ulum, Jatiroto, Lumajang, guna membahas masalah itu. ${ }^{50}$ Mereka melakukan semacam otokritik terhadap lembaga Syuriah yang dianggap menjadi penyebab mandulnya tradisi

49 Husein Muhammad, Fikih Perempuan: Refeksi Kritik atas Wacana Agama dan Gender (Yogyakarta: LKiS, n.d.), 138.

50 Agenda itu menghasilkan catatan-catatan otokritik berupa persoalan-persoalan yang meliputi; pertama, pemahaman kitab masih tekstual (harfiah), yaitu kurang mampu mengaitkan dengan persoalan-persoalan nyata yang terjadi di masyarakat, baik yang bersifat lokal maupun trans-nasional; kedua, kurang informasi, terutama yang berkaitan dengan kenyataan dan isu mutakhir dalam kehidupan masyarakat, baik menyangkut politik, ekonomi maupun budaya; ketiga, minus pemahaman terhadap sejarah kehidupan dan pertumbuhan Islam; keempat, konsep tentang ibadah masih terbatas pada ibadah qashirah (manfaatnya dirasakan sendiri), belum muta'addi (manfaatnya dirasakan orang banyak); kelima, kompleksitas perkembangan masyarakat belum diimbangi oleh penguasaan ilmu yang memadai; keenam, kurang jelasnya wawasan keagamaan yang berkaitan dengan kehidupan. lihat. Djohan Effendi, Pembaruan tampa Membongkar Tradisi, 175. 
intelektual NU dalam melahirkan produk hukum selama ini. Menanggapi kritik-kritik di atas, melalui Muktamar NU di Cipasung pada tahun 1994, lembaga Syuriah NU melakukan perluasan pembahasan lewat forum bahtsul masa'il sebagai forum yang membahas almasa'il aldiniyyah, dari persoalan yang semula hanya terbatas pada almasa'il alfiqhiyah, menjadi almasa'il almaudbu'iyyah (masalah-masalah tematik mendasar, seperti sosial, politik, budaya) dan almasa'il alwaqi'iyah (masalah-masalah kecil). ${ }^{51}$

Forum babtsul masa'il yang mengupas berbagai kitab kuning (bahtsulkitab) diprakarsai oleh cendekiawan muda NU, Masdar Farid Mas'udi. Mereka yang mendapat dukungan penuh dari Gus Dur dan kiai senior, seperti kiai Sahal Mahfudh dan kiai Imron Hamzah sangat gencar mengkritisi kitab kuning yang sejak semula dianggap sakral, terutama kitab-kitab yang menjadi referensi pesantren NU. Sayangnya, kegiatan ini tidak berlangsung lama lantaran dianggap menyimpang dari tradisi NU. Bahkan, mereka memperoleh resistensi dari sejumlah kiai sepub NU, sehingga membuat kegiatan tersebut terhenti.

Adanya sejumlah resistensi tidak lantas membuat Masdar menyerah. Masdar yang pada waktu itu menjadi penanggungjawab Program Pengembangan Pesantren (P3M), dibantu oleh Rabithah Ma'ahid Alislamiyah (RMI) melakukan kegiatan seminar yang disebut halaqo $^{52}$ untuk mewadahi berbagai gagasan kiai muda NU yang haus akan perubahan. Halaqoh ini dilakukan untuk memahami kitab kuning secara kontekstual. Adapun kerangka kerja dan titik fokus pengembangan halaqoh mengambil pesan kiai Zaini yang pernah mewariskan gagasan tentang alwa'şh alkhamsah (lima wawasan). Kelima wawasan itu adalah: alwa'zh aldini (wawasan keagamaan), alwa'z̧ al'ilmi (wawasan keilmuan), alwa'ž alijtima'i

51 Djohan Effendi, Pembaruan tanpa Membongkear Tradisi, 175-176.

52 Halaqoh, secara harfiah berarti "lingkaran". Ungkapan ini pertama kali muncul di kalangan akademik pada tahun 1987 oleh P3M. Digunakan sebagai nama forum seminar para kiai-terutama di kalangan NU-dalam membicarakan kontekstualisasi kitab kuning dan persoalan-persoalan lain yang berkaitan dengan persoalan syu'un ijtima'iyah. Dalam KBBI online dimaknai sebagai sarasehan; cara 
(wawasan kemasyarakatan), alwa'z̧ alniz̧hami (wawasan keorganisasian) dan alwa'sh alsya'bi wa albukmi (wawasan nasional dan kepemerintahan). ${ }^{53}$

Lambat laun, forum halaqoh menjadi arus utama gerakan intelektualisme NU. Melalui forum inilah generasi muda NU banyak menelurkan ijtihad yang produknya menjadi rekomendasi Muktamar dan Munas Alim Ulama NU. Salah satu rekomendasi penting dari hasil balaqob yang kemudian dibawa pada Musyawarah Nasional Alim Ulama di Bandar Lampung pada Februari 1992 adalah keputusan halaqoh bertema "Menganut Madzhab dalam Konteks Masa Kini”. Tema halaqob yang dibahas selama dua tahun berturut-turut-yaitu di Banyu Putih Jawa Timur tahun 1989 dan di pesantren Mamba’ul Ma'arif, Denanyar, Jombang tahun 1990_ itu menghasilkan dua metodologi bermadzhab, yaitu metode bermadzhab qauly dan metode bermadzhab manhajy. ${ }^{54}$ Keputusan inilah yang disebut sebagai titik awal pergeseran paradigma fikih NU, yang semula bersifat qauly, kini merambah—untuk tidak mengatakan meninggalkan— manhajy.

belajar atau mengajar dengan duduk di atas tikar dengan posisi melingkar atau berjejer. lihat. http://kbbi.web.id/halakah.html diakses pada 31 Juli 2018.

53 Djohan Effendi, Pembaruan tanpa Membongkar Tradisi, 179.

${ }^{54}$ Munas Alim Ulama di Bandar Lampung menjadi titik awal pergeseran paradigma fikih NU. Meski demikian, keputusan mengambil langkah manhajy dalam babtsul masa'il NU dilakukan apabila metode qauly tidak lagi memadai. Pada Munas tersebut, mereka berhasil merumuskan mekanisme ijtihad dalam mengambil keputusan hukum (istinbath albukm). Mekanisme istinbath alhukm tersebut meliputi: pertama, dalam kasus ketika jawaban dapat dicakup oleh ibarah dan di sana hanya terdapat satu qaul/wajah, maka dipakai qaul/wajah sebagaimana diterangkan dalam ibarah kitab tersebut; kedua, dalam kasus ketika jawaban dapat dicakup dalam 'ibarah kitab dan di sana terdapat lebih dari satu qaul/wajah, maka dilakukan taqrir jama'i (upaya kolektif dalam menetapkan pilihan hukum atas beberapa qaul) untuk memilih satu qaul/wajab; ketiga, dalam kasus tidak ada qaul/ wajah sama sekali yang memberi penyelesaian, maka dilakukan prosedur ilhaq almasa'il bi nadhairiha (menyamakan hukum suatu masalah yang tidak dibahas dalam kitab tertentu dengan kasus serupa yang telah dibahas dalam kitab yang lain) secara jama'i oleh ahlinya; keempat, dalam kasus yang tidak ada qaul sama sekali dan tidak mungkin dilakukan ilhaq, maka dilakukan istinbath jama'i dengan prosedur bermadzhab secara manbajy oleh para ahlinya. Lihat, Muhammad Ulil Abshor, "Dinamika Ijtihad Nahdlatul Ulama (Analisis Pergeseran Paradigma dalam Lembaga Bahtsul Masail NU)," Millati, Journal of Islamic Studies and Humanities 1, no. 2 (2016): 227-242. 
Sebuah keputusan bersejarah bagi NU, berhasil mereka mengintegrasikan metode bermadzhab qauly dan metode bermadzhab manhajy. Melalui kedua madzhab fikih itu mereka mengalami perkembangan signifikan. Dalam waktu dekat mereka telah merambah pada isu-isu kontemporer seperti korupsi, HAM, ekonomi, kedudukan wanita, civil society, demokrasi, hutang luar negeri, lingkungan hidup, reksadana, hingga persoalan bom bunuh diri. Menariknya, sumber hukum yang digunakan juga tidak terpaku pada kitab kuning semata. Alqur'an, Alhadith, Tafsir, Qawaid Alushul, Qawa'id Alfigh, realitas sosial menjadi rujukan yang tidak lagi diabaikan. Bahkan tidak segan mereka menghadirkan pakar akuntabel yang memiliki kredibilitas jika masuk dalam kasus-kasus aktual..$^{55}$

\section{Depolitisasi NU: dari Politik Struktural ke Politik Kultural}

Munas Alim Ulama NU tahun 1983 dan Muktamar NU di Situbondo tahun1984 menunjukkan telah terjadi perubahan besar di tubuh NU. Sebuah peristiwa yang acapkali dimaknai sebagai kilas-balik sejarah NU. Rekonsiliasi politik dengan rezim Orde Baru yang ditandai dengan kembalinya NU ke khittah 1926, berarti bahwa secara organisasional NU keluar dari politik praktis. Para kiai dan politisi NU bebas berafiliasiwaktu itu ditujukan kepada Golkar dan PPP—kepada partai politik manapun. Saat itu pula NU kembali menjadi jam'iyyah diniyah yang fokus pada penyelesaian persoalan syu'un ijtima'iyyah seperti pendidikan, ekonomi, kebudayaan, dan sosial-keagamaan.

Terdapat banyak cara pandang pengamat dalam memahami keputusan NU untuk kembali ke khittah 1926. Sebagian memahami sebagai strategi perang politik setelah tidak mampu keluar dari cengkraman kekuatan Orde Baru, yang semula melalui perlawanan politik struktural dan kemudian memilih jalan dengan perlawanan politik kultural. Anggapan ini menjadi absah ketika merujuk pada doktrin politik Sunni yang bersifat elastis, sebagaimana diajarkan oleh Imam Almawardi. Ciri khas politik Sunni adalah tidak pernah menganjurkan kadernya untuk menjadi oposisi

55 As'ad Said Ali, Pergolakan di Jantung Tradisi: NU yang Saya Amati, 191-193. 
terhadap penguasa; dengan catatan selama tetap berpegang teguh pada prinsip-prinsip keislaman. ${ }^{56}$ Secara umum, pengikut pemikiran politik Sunni biasa disebut ablussunnah wa aljama'ah yang selain memiliki pemikiran bidang fikih dan teologi, juga memiliki pemikiran bidang politik. ${ }^{57}$

Teori politik Sunni ini sangat besar mempengaruhi pemikiran politik para penganutnya, sesuai dengan rujukan makna dasar kekhalifahan yang dianutnya. Dalam makna politik yang dianut Sunni, kekhalifahan merujuk pada wewenang seseorang yang berfungsi sebagai pengganti Nabi dalam kapasitasnya sebagai pemimpin masyarakat, bukan dalam fungsi dan kapasitas sebagai kenabiannya. ${ }^{58}$ Fungsi kekhalifahan sebagai penjaga agama dan mengatur dunia. Oleh karena itu, pengangkatan kepala negara untuk memimpin umat adalah wajib menurut ijma, ${ }^{59}$

Sementara itu, selain strategi perlawanan politik, sebagian lagi memahami bahwa keputusan kembali ke khittah 1926 merupakan wujud atas pragmatisme politik NU yang kerap mendapat tekanan dari penguasa dalam segala aktivitasnya, sehingga berpolitik di jalur struktural nyaris tidak menguntungkan sama sekali bagi NU. Seperti halnya Robin Bush yang berkesimpulan bahwa berpolitik di jalur kultural bagi NU tidak lebih dari sekadar pelarian atas tekanan rezim Soeharto. Kembalinya NU ke khittah tetap menjadi strategi manuver 'politik tanpa panggung' dalam memperjuangkan cita-cita sosial-politiknya ${ }^{60}$ Terlepas dari semua opini yang menggelembung, keputusan NU untuk kembali ke kbittah 1926 merupakan kelanjutan dari misi kemanusiaan para ulama dan intelektual

56 Greg Fealy, Ijtihad Politik Ulama: Sejarah NU 1952-1967 (Yogyakarta: LKiS, 2003). Lihat juga. Masyhur Amin, NU dan Ijtihad Politik Kenegaraan (Yogyakarta: Al-Amin Press, 1996).

57 John L. Esposito, "Sunni," Ensiklopedi Oxford: Dunia Islam Modern (Mizan, 2001), 259-266.

58 Khalid Ibrahim Jindan, Teori Politik Islam: Telaah Kritis Ibnu Taimiyah tentang Pemerintahan Islam (Surabaya: Risalah Gusti, 1995), 8.

59 Almawardi, "Alahkam Alsulthaniyyah wa Alwilayatu Aldiniyyah," dalam Avonturisme NU: Menjajaki Akar Konflik, Kepentingan-Politik Kaum Nabdhiyyin, ed. Ali Anwar (Bandung: Humaniora, 2004), 8.

${ }^{60}$ Robin L. Bush, "Redefinging 'Political Islam' in Indonesia: Nahdlatul Ulama and Khittah '26," Studia Islamika 7, no. 2 (2000): 81-82. 
NU yang masih peduli dan menginginkan NU kembali berdakwah di jalur kultural, setelah auratnya "ditelanjangi” oleh sebagian kadernya sendiri.

Depolitisasi NU dalam banyak hal telah merangsang intelektualisme para generasi muda NU untuk mengembangkan wacana keislaman yang didasarkan pada pengembangan fikih kerakyatan dan teologi pembangunan — meski dalam kenyataannya di beberapa daerah mayoritas NU, masih kerap juga ditemui politisi NU yang mencoba menancapkan kekuasaan dalam dominasi PPP. ${ }^{11}$ Semenjak depolitisasi, aktivitas NU memang lebih banyak dialihkan pada arena politik kultural. Banyak kader NU menempuh pendidikan tinggi dan sebagian bergabung dalam komunitas NGO. Mereka menjadi penyalur mobilitas intelektual komunitas NU. Mereka pula yang mengembangkan wacana intelektual baru di lingkungan NU setelah mereka mengalami mobilitas sosial-intelektual dalam pendidikan formal dan komunitas-komunitas NGO.

Suatu keuntungan besar bagi mereka, ketika mereka sedang bersemangat membangun teologi aplikatif, support perlindungan-lihatlah saat Kiai sepub NU menyerang generasi muda NU yang wacananya dipandang telah keluar dari tradisi NU, Gus Dur menjadi perisai kokoh yang melindungi mereka dari serangan para Kyai sepub NU-dan sumbangan pemikiran yang begitu besar dari figur lokomotif gerakan kultural membuat wacana intelektualisme NU nyaris tidak tertandingi oleh komunitas lain. Bahkan dalam konstruksi subyektivitas tertentu, Ahmad Baso memberi penekanan bahwa wacana NU studies melampaui Islamic Studies. ${ }^{62}$

Upaya para ulama-intelektual NU untuk mengembalikan NU ke khittah 1926 bukan berarti tanpa alasan. Ketika NU menjadi partai politik tahun 1952, tujuan NU tidak lebih sekadar merebut posisi dan menumpuk materi. Tesis ini diperkuat oleh temuan Greg Fealy yang menyebut bahwa

${ }^{61}$ Yanwar Pribadi, "Religious Networks in Madura: Pesantren, Nahdlatul Ulama, and Kiai as the Core of Santri Culture," Aljami'ab: Journal Of Islamic Studies 51, no. No. 1 (2013): 15 .

62 Ahmad Baso, NU Studies: Pergolakan Pemikiran antara Fundamentalisme Islam dan Fundamentalisme Neo-Liberal (Jakarta: Erlangga, 2006),14-16. 
misi NU menjadi partai politik hanya; a) menyalurkan dana pemerintahan kepada struktural NU, terutama meningkatkan fasilitas pendidikan, kesehatan, dan sosial-keagamaan; b) berusaha mendapatkan peluang bisnis dari pemerintah kepada elit NU; dan c) mendapat kedudukan bagi elit NU dalam birokrasi. ${ }^{63}$

Sementara menurut Ahmad Nurhasim dan Nur Kholik Ridwan, konteks sosial yang mengiringi munculnya gagasan khittah 1926 sebagai mainstream gerakan adalah; pertama, adanya tuntutan terhadap penguatan pemberdayaan masyarakat yang lebih massif guna mengimbangi kuatnya hegemoni negara. Saat khittah dimunculkan, rezim represif memang sedang dalam kondisi digdaya, di saat yang sama masyarakat dihegemoni secara beringas. ${ }^{64}$ Salah satu draf yang dibuat para aktivis NU yang concern terhadap persoalan sosial, menurut pengakuan Bruinessen selain mendesak agar NU kembali ke kbittah mereka juga mengkritik cengkraman negara. ${ }^{65}$

Kedua, perpolitikan NU banyak berkhidmat pada politik praktis. Secara internal, keadaan politik NU sebelum khittah banyak tergerus oleh aktivitas politik praktis, sehingga mengabaikan primordialisme perjuangannya. Hal ini tampak jelas ketika Mitsuo Nakamura membagi periode perkembangan NU yang lebih banyak berkhidmat pada politik praktis. ${ }^{66}$

Ketiga, semangat untuk membangun warga NU yang marjinal dalam berbagai bidang. Keinginan untuk mengikis banyaknya warga NU yang marjinal merupakan implementasi dari poin pertama. Bruinessen menulis, "Muktamar Situbondo mewakili kemenangan kelompok interested dalam

${ }^{63}$ Greg Fealy, Ijtihad Politik Ulama: Sejarah NU 1952-1967, 98.

${ }^{64}$ Ahmad Nurhasim dan Nur Kholik Ridwan, Demoralisasi Kbittah NU dan Pembaruan (Yogyakarta: LKiS, 2004), 26-33.

${ }^{65}$ Martin Van Bruinessen, "Perjuangan Meraih Kekuasaan dan Keprihatinan Sosial: Catatan Muktamar Krapyak," in Tradisionalisme Radikal: Persinggungan NU-Negara, ed. Greg Fealy dan Greg Barton (Yogyakarta: LKiS, 1997), 133.

${ }_{66}$ Mitsuo Nakamura, "Tradisionalisme Radikal: Catatan Muktamar Semarang 1979,” d Tradisionalisme Radikal: Persinggungan NU-Negara, ed. Greg Fealy dan Greg Barton (Yogyakarta: LKiS, 1997), 58. 
pengembangan masyarakat. Hal itu tercermin dalam program kerja yang berisi bagian panjang kerja sosial, usaha ekonomi (kemandirian mengembangkan desa), dan peningkatan kondisi tenaga kerja". ${ }^{67}$

Dengan demikian, meretas ulang khittah dengan mengusung semangat sosial-keagamaan merupakan keputusan yang primordial. Sebab, seperti pernah dikatakan Gus Dur, “orang-orang NU, terlepas dari beberapa gelintir Kiai dan politisi urban yang sukses, mereka terpinggirkan di semua lapisan". Depolitisasi NU merupakan langkah revolusioner bagi NU untuk kembali menjadi jam'iyyah diniyah yang perjuangannya dapat dirasakan semua lapisan.

\section{Penutup}

Kajian terhadap genealogi revolusi paradigma keislaman NU menghasilkan temuan adanya latar belakang pemikiran yang tidak monolitik. Genealogi revolusi paradigma keislaman NU muncul akibat dialektika internal dan sentuhan eksternal yang dijembatani oleh multiepistemologi. Dialektika internal NU terjadi akibat: (1) pergeseran arah kiblat organisasional dari jalur politik struktural ke jalur politik kultural; (2) kemunculan figur lokomotif gerakan intelektual di elit struktural yang menjadi penghubung jurang tradisionalisme dan modernisme; (3) mobilitas sosial-intelektual sebagai buah dibukanya Perguruan Tinggi Keagamaan Islam Negeri yang memberi peluang santri mengikis isolasi.

Sementara sentuhan eksternal setidaknya terjadi akibat kemunculan arus intelektualisme di belahan dunia Arab yang kemudian mendiversifikasi wacana pemikiran keislaman NU dari monokultur menjadi multikultur; (2) adanya proyek pengembangan masyarakat melalui pesantren yang dipelopori oleh LP3ES dan P3M menjadi momentum kebangkitan kaum marjinal. Adapun bentuk revolusi paradigma keislaman

${ }^{67}$ Bruinessen, "Perjuangan Meraih Kekuasaan dan Keprihatinan Sosial: Catatan Muktamar Krapyak.”, 133. 
NU meliputi: (1) revolusi pemahaman terhadap Aswaja yang tidak sekadar dipahami sebagai dogma, tetapi sebagai manhaj alfikr (metode berpikir); (2) perluasan cara istinbat hukum fikih NU dari qauly ke manhajy; dan (3) depolitisasi NU dari politik struktural ke politik kultural. Inilah revolusi paradigma, sebuah pergeseran naluriah yang terjadi ketika primordialisme yang mapan tidak lagi relevan dengan perubahan.

\section{Referensi}

Abshor, Muhammad Ulil. "Dinamika Ijtihad Nahdlatul Ulama (Analisis Pergeseran Paradigma dalam Lembaga Bahtsul Masail NU)." Millati, Journal of Islamic Studies and Humanities 1, no. 2 (2016): 227242.

Achmad, Shiddiq. Khittah Nabdliyyah. Surabaya: Balai Buku, 2005.

Almawardi. "Alahkam Alsulthaniyyah Wa Alwilayatu Aldiniyyah." In Avonturisme NU: Menjajaki Akar Konflik, Kepentingan-Politik Kaum Nabdhiyyin, edited by Ali Anwar, 8. Bandung: Humaniora, 2004.

Ali, As'ad Said. Pergolakan di Jantung Tradisi: NU Yang Saya Amati. Jakarta: LP3ES, 2008.

Amin, Masyhur. NU dan Ijtihad Politik Kenegaraan. Yogyakarta: Al-Amin Press, 1996.

Azra, Azyumardi. Pergolakan Politik Islam dari Fundamentalisme, Modernisme bingga Postmodernisme. Jakarta: Paramadina, 1996.

Baso, Ahmad. "Neo-Modernisme Islam vs Post-Tradisionalisme Islam." Jurnal Tashwirul Afkear 10, no. No. 1 (2001): 32.

- NU Studies: Pergolakan Pemikiran antara Fundamentalisme Islam dan Fundamentalisme Neo-Liberal. Jakarta: Erlangga, 2006.

Bruinessen, Martin van. Kitab Kuning, Pesantren dan Tarekat. Bandung: Mizan, 1995.

Bruinessen, Martin Van. NU: Tradisi, Relasi-Relasi Kuasa, Pencarian Wacana Baru. Yogyakarta: LKiS, 1999.

. "Perjuangan Meraih Kekuasaan dan Keprihatinan Sosial: Catatan Muktamar Krapyak." In Tradisionalisme Radikal: Persinggungan NUNegara, edited by Greg Fealy dan Greg Barton, 133. Yogyakarta: LKiS, 1997. 
Buchori, Moh. Najib. "Aqidah Aswaja dan Pembangunan Manusia: Upaya Menemukan Aqidah Alternatif dagi Kebangkitan Umat Islam." Nuansa: Jurnal Kajian Keislaman Keluarga Mahasiswa Nabdlatul Ulama Cabang Mesir, no. No. 1 (1997): 3.

Bush, Robin L. "Redefinging 'Political Islam' in Indonesia: Nahdlatul Ulama and Khittah '26." Studia Islamika 7, no. No. 2 (2000): 81-82.

Bush, Syafiq Hasyim dan Robin. "NU and Discourses: Islam, Gender Right, and Traditional Islamic Society." In Conference on Islam, Civil Society, and Development in Southeast Asia. Melbourne: University of Melbourne, 1998.

Effendi, Djohan. Pembaruan Tanpa Membongkar Tradisi. Jakarta: Kompas, 2010.

Esposito, John L. "Sunni." Ensiklopedi Oxford: Dunia Islam Modern. Mizan, 2001.

Fealy, Greg. Ijtihad Politik. Ulama: Sejarah NU 1952-1967. Yogyakarta: LKiS, 2003.

Ghazali, Imam. "Aswaja Klaim Nahdlatul Ulama: Pembakuan Terhadap Kemapanan dalam Visi Anak Muda Nahdlatul Ulama." Nuansa: Jurnal Kajian Keislaman Keluarga Mahasiswa Nabdlatul Ulama Cabang Mesir, no. No. 1 (n.d.): 4.

Haidar, M. Ali. Nabdlatul Ulama dan Islam di Indonesia: Pendekatan Fikih dalam Politik. Jakarta: Gramedia, 1998.

Hasan, M. Tolchah. Metode Pengajian Kitab di Pesantren: Tinjanan Ulang Pesantren. Jakarta: P3M, 1989.

Ida, Laode. NU Muda: Kaum Progresif dan Sekularisme Baru. Jakarta: Erlangga, 2004.

Jamil, M. Mukhsin. Nalar Islam Nusantara: Studi Islam ala Mubammadiyah, Alirsyad, Persis dan NU. Jakarta: Direktorat Pendidikan Tinggi Islam, 2007.

Jindan, Khalid Ibrahim. Teori Politik Islam: Telaah Kritis Ibnu Taimiyah tentang Pemerintahan Islam. Surabaya: Risalah Gusti, 1995.

Kuhn, Thomas S. The Structure of Scientific Revolutions. Chicago: University of Chicago Press, 2012.

Madany, Abdul Malik. "Posisi Kitab Kuning dalam Khazanah Keilmuan." In Pembaruan tanpa Membongkar Tradisi, edited by Djohan Efendi, 167-168. Jakarta: Kompas, n.d. 
Mahfudz, Sahal. Nuansa Fikih Sosial. Yogyakarta: LKiS, 1994.

Masyhuri, Muhammad. "NU dan Paradigma Teologi Politik Pembebasan: Refleksi Historis Pasca Khittah.” Wawasan: Jurnal Ilmiah Agama dan Sosial Budaya 1, no. 2 (2016): 158-178.

Muhammad, Husein. Altsimarul-Yani'ah fi Riyadh Albid'ah Karya Syeikh Mubammad Nawawi Albantani. Cisarua, 1994.

- Fikih Perempuan: Refeksi Kritik atas Wacana Agama dan Gender. Yogyakarta: LKiS, n.d.

Nakamura, Mitsuo. "Tradisionalisme Radikal: Catatan Muktamar Semarang 1979.” In Tradisionalisme Radikal: Persinggungan NU-Negara, edited by Greg Fealy dan Greg Barton, 58. Yogyakarta: LKiS, 1997.

Niam, Khoirun. "Nahdlatul Ulama and the Production of Muslim Intellectuals in the Beginning of 21 st Century Indonesia." Journal of Indonesian Islam 11, no. 02 (2017): 351-388.

Nurhisam, Luqman, and Mualimul Huda. "Islam Nusantara: A Middle Way?" QIJIS: Qudus International Journal of Islamic Studies 4, no. 2 (2016): 152-166.

Nurkhalis. "Konstruksi Teori Paradigma Thomas S. Kuhn.” Jurnal Ilmiah Islam Futura 11, no. No. 2 (2012): 79-99.

Pribadi, Yanwar. "Religious Networks in Madura: Pesantren, Nahdlatul Ulama and Kiai as the Core of Santri Culture." Aljami'ah: Journal Of Islamic Studies 51, no. No. 1 (2013): 15.

Ridwan, Ahmad Nurhasim dan Nur Kholik. Demoralisasi Kbittah NU dan Pembaruan. Yogyakarta: LKiS, 2004.

Rumadi. Post Tradisionalisme Islam: Wacana Intelektualisme dalam Komunitas NU. Cirebon: Fahmina Institute, 2008.

Siradj, Said Aqil. Ablussunnah dalam Lintasan Sejarah. Yogyakarta: LKPSM, 1997.

Umar, Ahmad Rizky Mardhatillah. "A Genealogy of Moderate Islam: Governmentaly and Discourses of Islam in Indonesia's Foreign Policy." Studia Islamika 23, no. N0. 3 (2016): 414-418.

Wahid, Abdurrahman. Islam Kosmopolitan: Nilai-Nilai Keindonesiaan dan Transformasi Kebudayaan. Jakarta: The Wahid Institute, 2007. 
AL-A'RAF - Vol. XV, No. 2, Juli - Desember 2018 